\title{
Polypore survey of Finland 2. The genus Phellinus
}

\author{
TUOMO NIEMELÄ and HEIKKI KOTIRANTA
}

NIEMELÄ, T. \& KOTIRANTA, H. 1982: Polypore survey of Finland 2. The genus Phellinus. - Karstenia 22: 27--42.

Distribution maps are presented for all the species of Phellinus occurring in Finland and host plant statistics are given for each species. The ecological characteristics and pathogenicity of the species are discussed, and an evaluation made of their economic importance as pathogens and wood-rotting fungi on merchantable timber and ornamental trees and shrubs.

At present 18 species of Phellinus are known to occur in Finland, 13 on deciduous and 5 on coniferous trees. The most important hardwood-decaying species is $P$. igniarius (L.) Quél., followed by $P$. tremulae (Bond.) Bond. \& Borisov, which infects Populus tremula. Of the conifer-decaying species, the most harmful is $P$. chrysoloma (Fr.) Donk (on Picea abies, especially in northern Finland), followed by a much less important species, P. pini (Brot.) A.Ames on Pinus sylvestris.

The generic concept of Phellinus is briefly discussed, and some author citations are altered in the specific names according to the changes in the Code of Nomenclature enacted in 1981 .

Tuomo Niemelä and Heikki Kotiranta, Department of Botany, University of Helsinki, Unioninkatu 44, SF-00170 Helsinki 17, Finland

\section{Foreword}

The genus Phellinus is one of the largest and most important polypore genera represented in Finland. At present 18 species are known from the area, 13 of which grow on hardwoods and 5 on coniferous hosts. P. contiguus has not yet been recorded from Finland, but its occurrence in thickets of Hippophae rhamnoides on the eastern coast of Sweden suggests that it may occur in the south-western archipelago of Finland, too (Jahn 1965, 1967). For a description of the probable sites of $P$. contiguus, see the discussion of $P$. hippophaeicola (p. 31). Another species which has not been recorded, but might be found is $P$. hartigii. Bondarceva (1963) reports it from the neighbourhood of Leningrad, growing on Picea abies. The occurrence of $P$. hartigii in Finland seems to be less probable, however, than that of $P$. contiguus. The specific delimitation of $P$. alni Parmasto (1976) was difficult to establish from the Finnish material, and if present, it is included in P. igniarius.

The concept of Phellinus adopted here is the traditional one. The genus is obviously heterogeneous and will surely eventually be divided into more uniform entities. Traditionally, the genus has been defined by two features: a dimitic hyphal system and perennial fruit bodies, characters separating it from Inonotus and other genera of the old family of Hymenochaetaceae. The hyphal system is not a good character, however: P. ribis is monomitic, which is the reason why Ryvarden (1978) transferred it to Phylloporia. Also monomitic are $P$. ferrugineofuscus, $P$. pouzarii and $P$. fragrans (Kotlaba 1968, Larsen \& Lombard 1976), which have often been made dimitic 'by force', i.e., by regarding the long macrosetae in the trama as another type of hypha ('setoid skeletal hyphae' or 'setal hyphae'). In fact these macrosetae are just one type in the variable group of special cells called the setae, comparable with the hymenial setae (the commonest type), cuticular setae (in Inonotus cuticularis and others), core setae (in $P$. tremulae and allied species, Niemelä 1974), asterosetae (Asterodon, Donk 1964), etc. Further, the demarcation between the generative hyphae and skeletal hyphae proper is often vague or nonexistent (Jahn 1981) because of any number of intermediary forms. This may be seen for instance in the $P$. robustus group. Thus, only the perennial growth habit remains as a separating character for the genus (and for the family Phellinaceae, Jülich 1981), which is not very much.

The changes in the International Code of Botanical Nomenclature (Demoulin et al. 1981, Korf 1982) have necessitated some corrections in the author citations and the unfortunate but unavoidable replacement of the name $P$. pomaceus by $P$. tuberculosus. These corrections were made mainly according to the bibliographic information of Donk (1974). We are very grateful to Prof. Teuvo Ahti (Helsinki) for his notes and help in these problems.

For the general terms used in this survey, the material included, etc., the reader is referred to the Introduction to this series (Niemelä 1982b). As is explained there, the numbers in the host lists show the proportions of the collections made from each host, calcula- 
ted as the percentages of the total material for which a host was specified. The numbers following the names of the host genera include the percentages for the host species listed under the generic names. The sym- bol + represents a single collection.

In the following text the species of Phellinus are presented in alphabetical order, irrespective of their systematic positions.

Phellinus chrysoloma (Fr.) Donk

$\begin{array}{lccccc} & \begin{array}{c}\text { Whole of } \\ \text { Finland }\end{array} & \text { A-U } & \text { EK-PK } & \text { KP-PP } & \text { Ks-InL } \\ & 98.0 & 100 & 93.1 & 100 & 98.7 \\ \begin{array}{l}\text { Picea abies } \\ \text { Larix }\end{array} & 1.6 & - & 6.9 & - & - \\ - \text { sibirica } & + & & & & \\ - \text { decidua } & + & & - & + & + \\ \text { Pinus sylvestris } & 0.4 & - & - & & \\ \text { Host not indicated } & 13 & 38 & 58 & 87 & 82 \\ \text { Specimens examined } & 265 & 38 & & & \end{array}$

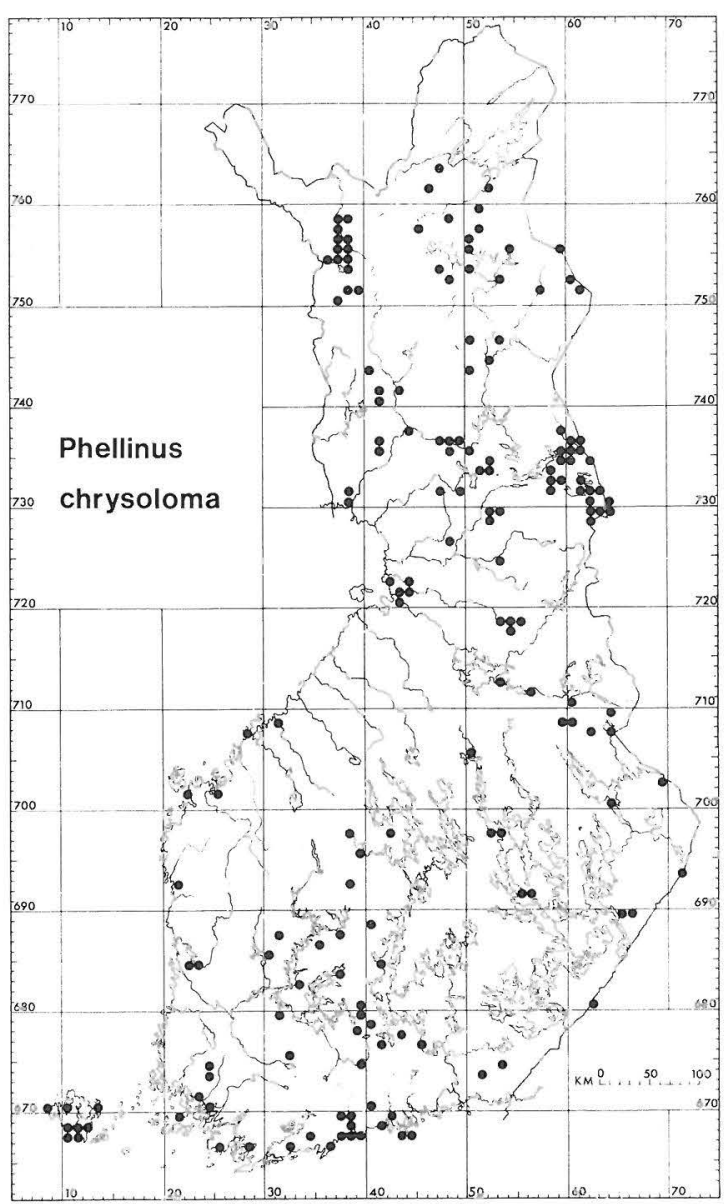

Distributed throughout the country, occurring on many of the isolated northernmost populations of $\mathrm{Pi}$ cea abies. In $\mathrm{S}$ and $\mathrm{C}$ Finland it is fairly rare to scattered, but around Pohjois-Pohjanmaa and Kainuu it becomes fairly common to common, and is very common in many important northern spruce forest areas. The distribution is distinctly northerly; besides being frequent in the north, it is also less exacting as regards its biotopes there. On the other hand, compared with, for example, $P$. ferrugineofuscus, it has a less continental distribution and has been collected many times in coastal Finland and the Åland archipelago.

The species occurs almost exclusively on Picea abies. The few records on the exotic tree genus Larix are from a single, old Larix plantation at Kitee, Pohjois-Karjala. The records on Pinus are exceptional, and made from fallen, still corticate trunks. It seems that these trunks had already fallen when they were infected.

$P$. chrysoloma occurs in $\mathrm{S}$ and $\mathrm{C}$ Finland in the richest, moist, dense climax spruce forests, mostly on old trees suffering from lack of light. In the north it can be found in all types of spruce forests, but seems to be commonest in moist hillside valleys and along brooks.

This is an important pathogen of living trees (Norokorpi 1979), although it seldom fruits before the tree has died. It first causes butt rot, which extends into both the heart- and sapwood, later decaying the roots and finally the central and upper central parts of the trunk, as well as the attached branches. The rot is brittle soft and lacunose (corrosion rot), of the delignifying type. The fruit bodies first appear around dead branches (especially if the tree is still living), 
later all over the still corticate trunk, often creeping along the branches and covering the undersides of fallen trunks with extensive resupinate fructifications.

In $N$ Finland $P$. chrysoloma belongs to a polypore community in which other characteristic species are Amylocystis lapponica, Fomitopsis rosea, Incrustoporia tschulymica and Leptoporus mollis (Kotiranta \& Niemelä 1981). The four last-mentioned species often occur together on trunks that have been killed by e.g. Fomitopsis pinicola, Onnia leporina or Climacocystis borealis. In contrast, the trees killed by $P$. chrysoloma bear few if any other saprophytic polypore species, evidently because of the strong competition from $P$. chrysoloma.

$P$. chrysoloma is economically unimportant in $\mathrm{S}$ and $\mathrm{C}$ Finland. In N Finland it is one of the most harmful parasites of spruce, causing extensive damage, especially in productive forests on the best sites. The characteristics of this damage have been described in N Sweden by Eriksson (1958, under Phellinus pini v. abietis).

Phellinus conchatus (Pers.) Quél.

\begin{tabular}{|c|c|c|c|c|c|}
\hline & $\begin{array}{l}\text { Whole of } \\
\text { Finland }\end{array}$ & A-U & EK-PK & KP-PP & Ks-InI \\
\hline Salix & 78.8 & 72.5 & 85.9 & 74.2 & 100 \\
\hline - caprea & 69.9 & & & & \\
\hline Syringa & 4.8 & 5.8 & 5.8 & - & - \\
\hline - vulgaris & 2.1 & & & & \\
\hline Lonicera xylosteum & 4.2 & 5.9 & 2.5 & 6.4 & - \\
\hline Populus tremula & 2.7 & 2.5 & 2.5 & 6.4 & \\
\hline Crataegus & 2.4 & 3.2 & 2.5 & - & - \\
\hline Prunus & 2.1 & 3.2 & - & 6.4 & 一 \\
\hline - padus & 1.8 & & & & \\
\hline - domestica & 0.3 & & & & \\
\hline Alnus & 1.5 & 1.3 & + & 6.4 & - \\
\hline - glutinosa & 0.6 & & & & \\
\hline Corylus avellana & 1.2 & 2.6 & - & - & - \\
\hline Ribes alpinum & 0.6 & + & + & - & - \\
\hline Sorbus aucuparia & 0.6 & 1.3 & - & - & - \\
\hline Tilia cordata & 0.6 & 1.3 & - & - & - \\
\hline Acer platanoides & + & + & - & - & - \\
\hline Betula & + & + & - & - & - \\
\hline Malus & + & + & - & - & - \\
\hline $\begin{array}{l}\text { Hos not indicated } \\
\text { Specimens }\end{array}$ & 54 & & & & \\
\hline examined & 387 & 183 & 148 & 31 & 25 \\
\hline
\end{tabular}

Distributed over most of Finland and apparently lacking only in northernmost Lapland. It is concentrated in the southern part of the country, where it is common, in suitable localities even very common. Its favourite host, the genus Salix, is abundant in all parts of Finland, and a strong preference for $S$. caprea is evident everywhere. When infecting that species, $P$. conchatus almost invariably attacks old trunks, and being a strong competitor may be a reason for the rarity of Haploporus odorus, another polypore on Salix caprea (Niemelä 1971).

No records exist from conifers. The abundance on the exotic host Syringa is interesting. S. vulgaris is one of the commonest small flowering trees used for garden decoration in $\mathrm{S}$ and $\mathrm{C}$ Finland, in both rural and urban areas. The third host, Lonicera xylosteum, is native though uncommon, and seldom becomes big enough for $P$. conchatus. The high rating of Lonicera

in the host list clearly shows the strong preference of the fungus for this rare host. In southern Finland $P$. conchatus grows on at least 15 host tree species, but in Lapland it is recorded only on Salix (mainly S. caprea).

The species favours hardwood or mixed forests at an early stage of succession, forest edges and other sites with fairly good illumination. In closed forests of the climax stage, it can be found only on dying trunks of Salix caprea. At first it is mostly a wound parasite, or infects dead branches and spreads from them into the living trunk. Though infecting only standing trees, it stays alive for a few years after they have fallen, then forming mostly resupinate fruit bodies.

Its economic importance is negligible, because the hosts are of minor importance. It causes some harm by destroying old lilacs in parks. 

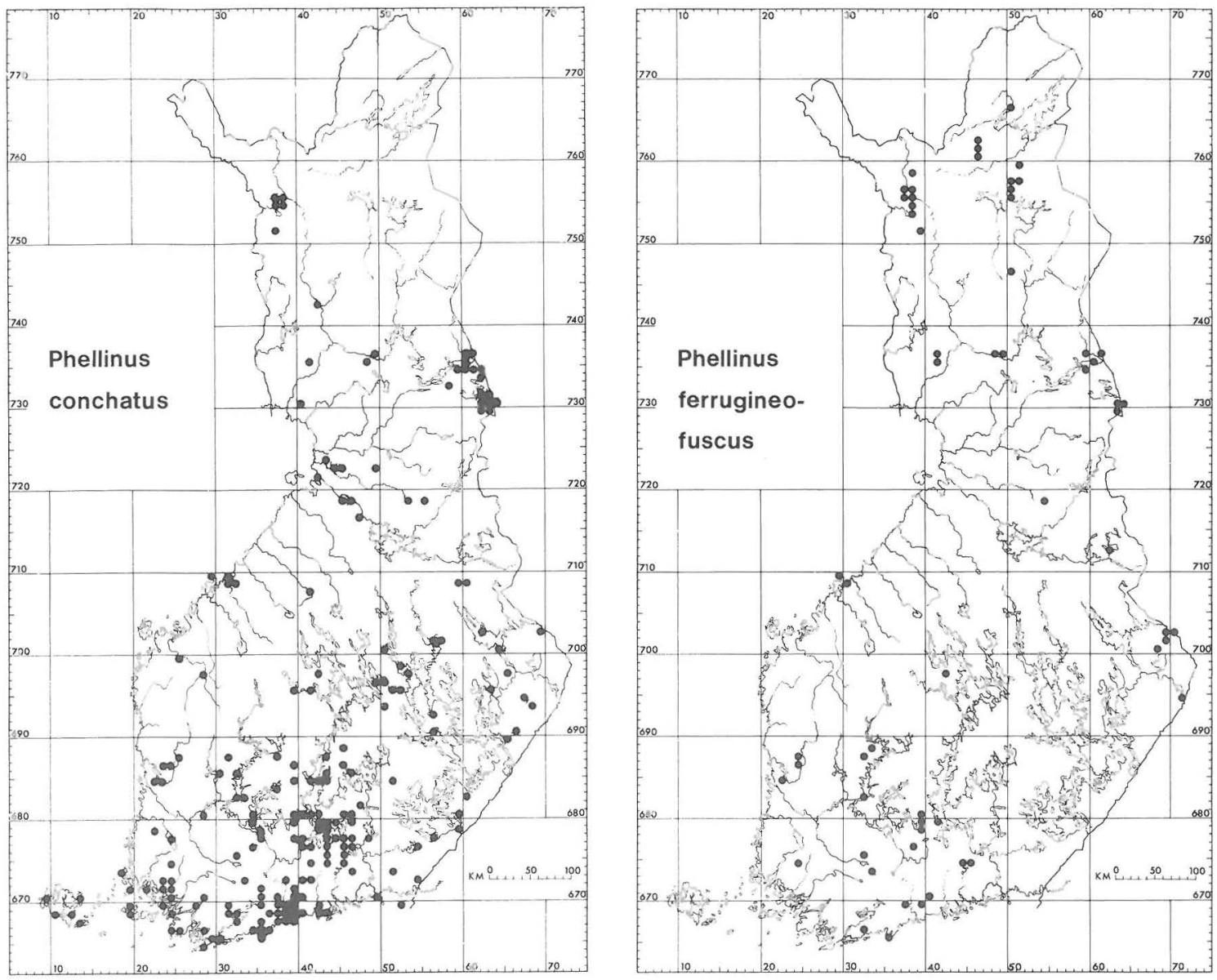

Phellinus ferrugineofuscus (Karst.) Bourd.

\begin{tabular}{|c|c|c|c|c|c|}
\hline & $\begin{array}{l}\text { Whole of } \\
\text { Finland }\end{array}$ & $\mathrm{A}-\mathrm{U}$ & EK-PK & KF-PP & $\mathrm{Ks}-\mathrm{InL}$ \\
\hline Picea abies & 90.8 & 91.0 & 92.0 & 85.0 & 93.3 \\
\hline Pinus sylvestris & 9.2 & 9.0 & 8.0 & 15.0 & 6.7 \\
\hline Host not indicated & 4 & & & & \\
\hline $\begin{array}{l}\text { Specimens } \\
\text { examined }\end{array}$ & 102 & 11 & 37 & 20 & 30 \\
\hline
\end{tabular}

Distributed all over the country, in S and C Finland rare, in N Finland fairly rare but locally even very common. Found only on conifers, $P$. ferrugineofuscus favours Picea abies very strongly.

Throughout its range, the species prefers mossy spruce forests of the climax stage, where the microclimate is humid, and its rarity in S Finland may be partly due to the scarcity of that type of forest there. However, the distribution is clearly concentrated in the north. This is evident from the fact that in Lapland it also occurs in open, well-illuminated upland spruce forests and not only in the richest, most sheltered biotopes.

In $\mathrm{N}$ Finland this is a member of the polypore community characterized by Amylocystis lapponica, Fomitopsis rosea, Incrustoporia tschulymica, Leptoporus mollis and (on separate tree trunks) Phellinus chrysoloma, which are called 'taiga species' by Eriksson \& Strid (1969), Eckblad (1981), and others.

$P$. ferrugineofuscus is found mostly on adult, often big, fallen, corticate spruce trunks, supported by branches so that they do not touch the ground. It causes extensive and intensive, finally brittle and soft white rot in the lower and central parts of the trunk, less often in its top. Whether it kills trees is not definitely known, but this is possible, since the rot is con- 
centrated at the base, and the fruit bodies appear on rather recently fallen, corticate trees and have also sometimes been found on long, standing stumps of broken trunks. In $\mathrm{S}$ and $\mathrm{C}$ Finland its rarity prevents the species from having any economic significance, but in N Finland it is an important decay-causing fungus of large, well-shaped, fallen spruce trunks.

\section{Phellinus ferruginosus (Scrad.) Pat.}

$\begin{array}{lr} & \mathrm{A}-\mathrm{V} \\ \text { Corylus avellana } & 90.0 \\ \text { Crataegus } & 5.0 \\ \text { Pyrus malus } & 5.0 \\ \text { Specimens examined } & 20\end{array}$

In Finland a strictly southern species, restricted to the climatically most favourable sites of the Hemiboreal zone, and even there very rare. The relatively high number of the specimens available for examination is due to regular revisiting of the few known sites.

$P$. ferruginosus mostly attacks small dead standing trunks of Corylus avellana, especially in places where the trunks touch each other. Also reported on Ulmus glabra in Aland by Laine (1967).

\section{Phellinus hippophaeicola Jahn \\ Whole of A-V St-EP KP Finland

$\begin{array}{lccccc}\text { Hippophae rhamnoides } & 100 & & & \\ \text { Specimens examined } & 46 & 41 & 4 & 1\end{array}$

Distributed in Finland in the Åland archipelago and along the coast of the Gulf of Bothnia. Evidently fairly common. The map includes some records from the literature (Vuoristo 1972, Vuoristo \& Rousi 1976), which are indicated by open squares. Earlier reported from Åland by Stenlid (1947), Schulmann (1960) and Laine (1967).

Being a species of Hippophae and Eleagnus (Jahn 1976), in Finland this polypore is bound to the occurrence of $H$. rhamnoides and thus restricted to a coastal strip on the southwestern shore of the Gulf of Bothnia. There the slow but continuous land upheaval offers foothold for a narrow but extensive belt of Sea Buckthorn thickets which spread on to the newly exposed land and degenerate in the older parts (Rousi 1971, Vuoristo \& Rousi 1976). These thickets offer an excellent substrate for $P$. hippophaeicola, and it appears to have a relatively continuous occurrence along this belt. A systematic study of this question has partly been prevented by practical difficulties. The host grows in a very dispersed outer archipelago, and the fruit bodies can be expected to be most frequent in the inner parts of the thorny, almost impenetrable bushes. This vegetation is (especially in Alland) the probable growth site of another species not yet recor-
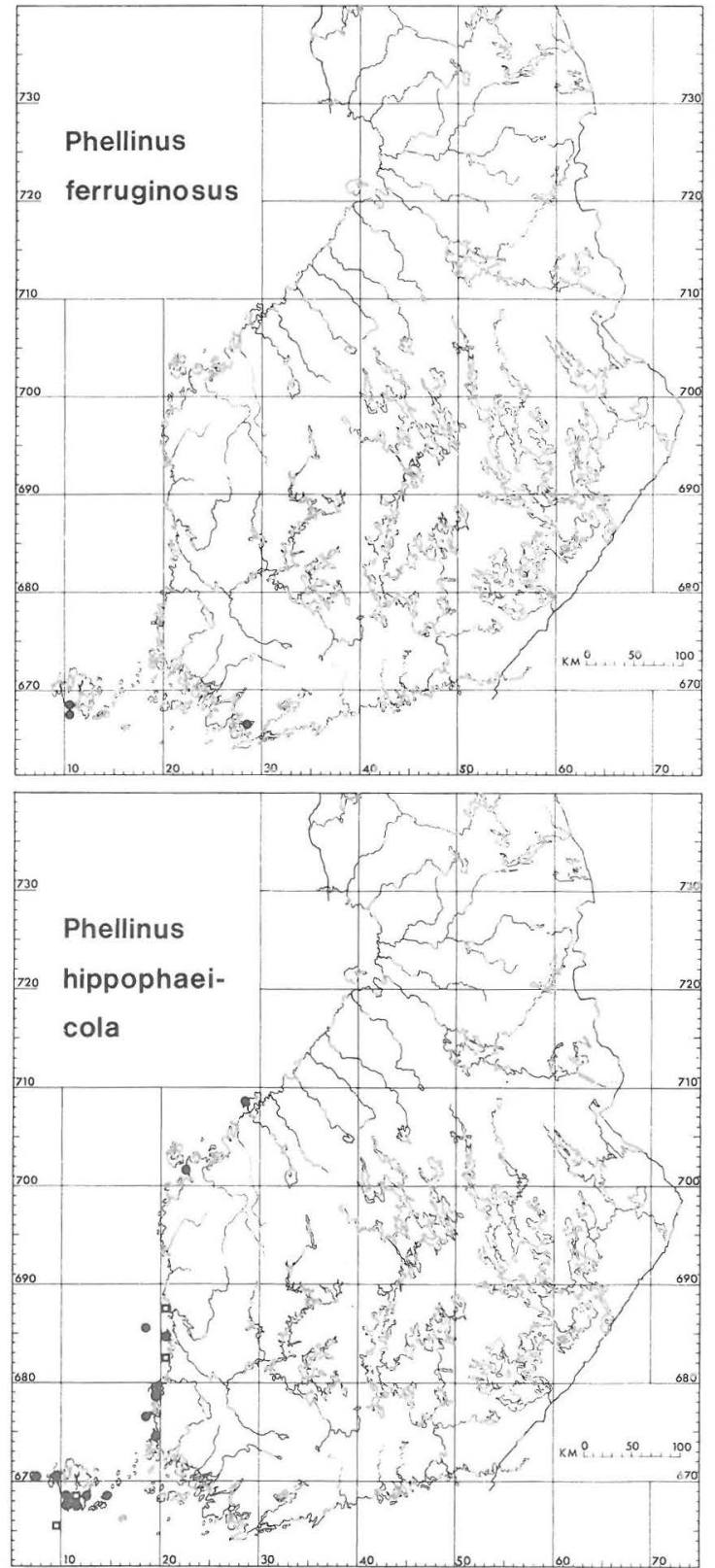

ded in Finland, Phellinus contiguus (Jahn 1965).

Since Hippophae rhamnoides does not occur on the Finnish coast of the Gulf of Finland, P. hippophaeicola is also absent there.

Besides some edaphic and other environmental changes, $P$. hippophaeicola is one of the major causes of the degeneration and death of old trunks of Hippophae rhamnoides. However, the fungus is well integrated in the continuous progress of this vegetation and does not endanger the existence of the Sea Buckthorn anywhere. 
Phellinus igniarius (L.) Quél.

\begin{tabular}{|c|c|c|c|c|c|}
\hline $\begin{array}{l}\mathrm{Y} \\
\mathrm{H}\end{array}$ & $\begin{array}{l}\text { Whole of } \\
\text { Finland }\end{array}$ & $A-U$ & EK-PK & KP-PP & Ks-In \\
\hline Betula & 39.2 & 21.7 & 44.7 & 39.2 & 80.0 \\
\hline - pubescens & 2.0 & & & & \\
\hline -- ssp. tortuosa & 1.3 & & & & \\
\hline Alnus & 18.2 & 13.4 & 20.0 & 19.6 & $8 . C$ \\
\hline - incana & 9.0 & & & & \\
\hline - glutinosa & 4.7 & & & & \\
\hline Salix & 16.0 & 22.2 & 10.6 & 23.9 & 10.6 \\
\hline - caprea & 5.3 & & & & \\
\hline - pentandra & 2.1 & & & & \\
\hline - fragilis & 1.6 & & & & \\
\hline - alba & 0.7 & & & & \\
\hline - myrsinifolia & 0.6 & & & & \\
\hline - X rubens & 0.6 & & & & \\
\hline - nigricans & 0.4 & & & & \\
\hline - phylicifolia & 0.4 & & & & \\
\hline - borealis & 0.3 & & & & \\
\hline - aurita & + & & & & \\
\hline \multicolumn{6}{|c|}{ - myrsinifolia $\times$ phylicifolia +} \\
\hline Sorbus & 8.5 & 12.1 & 8.0 & 8.7 & - \\
\hline - aucuparia & 7.0 & & & & \\
\hline - hybrida & 1.3 & & & & \\
\hline - intermedia & 0.2 & & & & \\
\hline Prunus & 4.2 & 6.3 & 3.0 & 4.3 & + \\
\hline - padus & 3.0 & & & & \\
\hline - cerasus & 1.0 & & & & \\
\hline - insititia & 0.2 & & & & \\
\hline Acer & 3.5 & 5.8 & 2.7 & 3.3 & - \\
\hline - platanoides & 3.4 & & & & \\
\hline - ginnala & + & & & & \\
\hline - negundo & + & & & & \\
\hline Corylus avellana & 3.0 & 6.7 & 2.0 & - & - \\
\hline Purys & 1.5 & 1.7 & 1.7 & - & - \\
\hline - malus & 0.2 & & & & \\
\hline Malus & 1.1 & 1.7 & 2.0 & - & - \\
\hline - domestica & 1.0 & & & & \\
\hline - prunifolia & + & & & & \\
\hline Quercus & 1.0 & 2.0 & 0.7 & - & - \\
\hline - robur & 0.9 & & & & \\
\hline - rubra & + & & & & \\
\hline Ulmus & 1.0 & - & 2.0 & + & - \\
\hline - glabra & 0.2 & & & & \\
\hline - leavis & 0.2 & & & & \\
\hline Juglans & 0.9 & 2.1 & + & - & - \\
\hline - cinerea & 0.4 & & & & \\
\hline Fraxinus excelsior & 0.6 & 1.3 & + & - & - \\
\hline \multicolumn{2}{|c|}{ Aesculus hippocastaneum 0.2} & 0.8 & - & - & - \\
\hline Populus & 0.2 & + & + & - & - \\
\hline - balsamifera & + & & & & \\
\hline - tremula & + & & & & \\
\hline Tilia cordata & 0.2 & 0.8 & - & - & - \\
\hline Crataegus & + & + & - & - & - \\
\hline Pterocarya rhoifolia & + & + & - & - & - \\
\hline Syringa vulgaris & + & - & + & - & - \\
\hline Host not indicated & 62 & & & & \\
\hline Specimens examined & 768 & 239 & 300 & 92 & 75 \\
\hline
\end{tabular}

Distributed over the whole country, and common to very common everywhere. P. igniarius has the widest host range within the genus. The proportion of the favourite host tree genus, Betula, rises towards the north, unlike that of all the other hosts. The genus Salix is fairly evenly represented in all parts of the country, but in S Finland most of those collections are from old park trees (e.g., S. alba, S. fragilis), while in the north they are chiefly from forest trees (e.g., Salix caprea). Remarkably few collections are from Populus tremula, which serves as a host for Phellinus populicola and $P$. tremulae.

$P$. igniarius is found in all types of forests and parks where hardwoods are represented. This wide amplitude is explained by the vast range of ecological adaptations in this polymorphic species. The four varieties of $P$. igniarius (Niemelä 1975) were not distinguished in this study. The total distribution in Fennoscandia was presented by Niemelä (1975).

The species is at first a parasite, infecting trees through dead branches, frost cracks and wounds. During many years it causes a heart rot, which extends into the sapwood during the death of the tree. However, progress of the disease varies greatly between tree species. For instance, in Betula the disease rapidly becomes fatal, while in big Salix alba and $S$. fragilis park trees, fruit bodies persist during tens of years without causing any serious changes in the tree growth. After the death of the host, the fungus long continues its growth as a saprophyte.

$P$. igniarius is one of the most harmful pathogens of hardwoods in Finland. The greatest economic losses are caused by infection of the forest trees Betula pendula and B. pubescens, but the harm to park trees (especially Salix) is also considerable. 

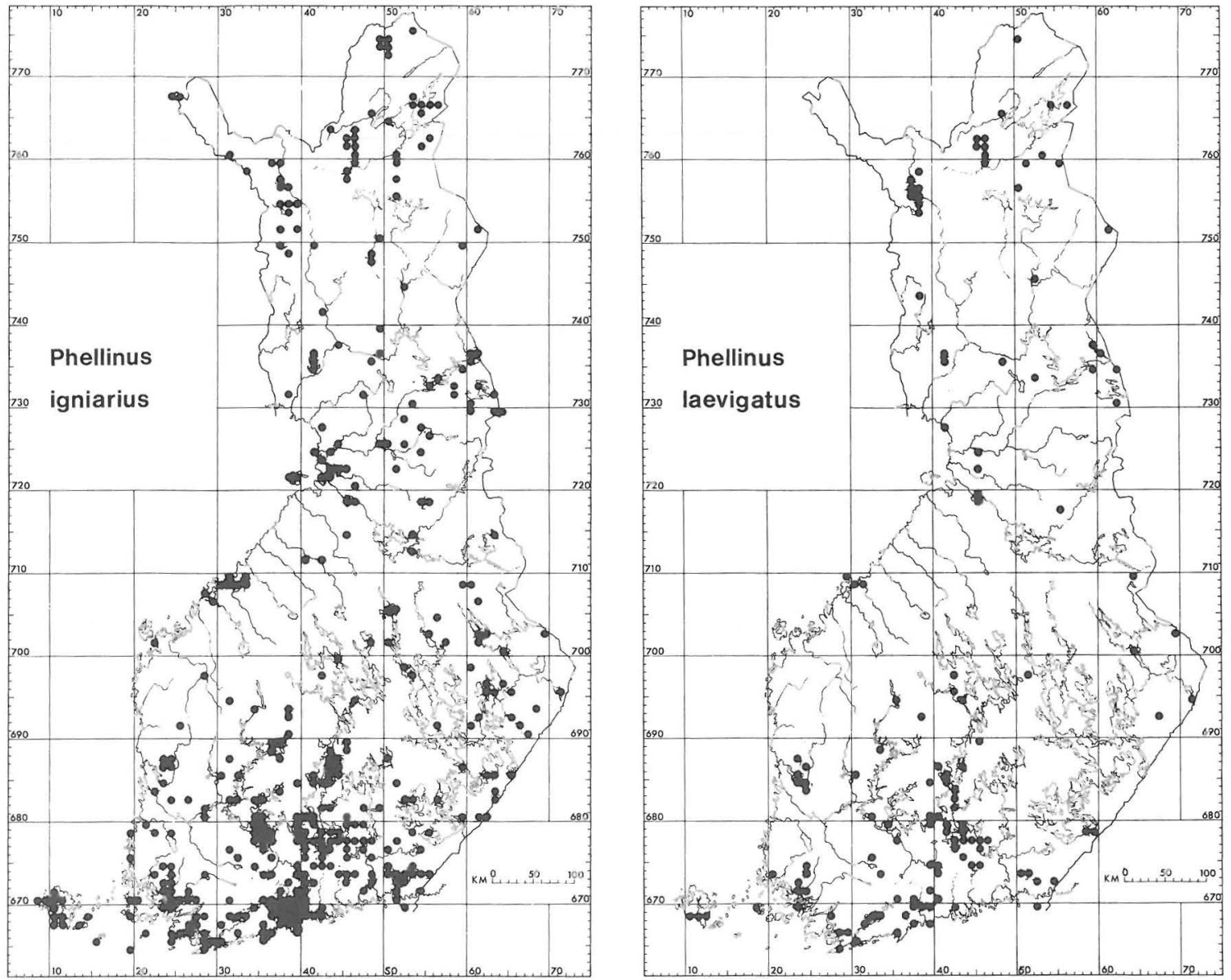

Phellinus laevigatus (Karst.) Bourd. \& Galz.

$\begin{array}{lccccc} & \begin{array}{c}\text { Whole of } \\ \text { Finland }\end{array} & \text { A-U } & \text { EK-PK } & \text { KP-PP } & \text { Ks-InL } \\ \text { Betula } & 95.0 & 94.3 & 93.1 & 100 & 100 \\ \text { - pubescens } & 3.1 & & & & \\ \text {-- ssp. tortuosa } & 1.5 & & & & \\ \text { - pendula } & 1.0 & & & & - \\ \text { Alnus } & 4.1 & + & 7.1 & - & - \\ \text { - incana } & 3.6 & & & & \\ \text { - glutinosa } & 0.5 & & & - & - \\ \text { Quercus robur } & + & + & - & - & - \\ \text { Sorbus aucuparia } & + & + & - & - & \\ \text { Host not indicated } & 8 & & & & \\ \text { Specimens } & & & & 104 & 31 \\ \text { examined } & 209 & 57 & 104 & & \end{array}$

Distributed throughout Finland, being scattered and nowhere common, though occurring relatively regularly in suitable forests. Almost entirely restricted to Betula, as elsewhere in Europe (Jahn 1981).

$P$. laevigatus prefers old and dense spruce forests interspersed with birch. It is almost invariably found on fallen, still corticate trunks, and only exceptionally on dead, still standing trees. Though the specimens are mostly resupinate, the species fairly often forms small and flattened true pilei with a grey-brown crust 
and very thin context (Niemelä 1972). These are formed almost exclusively on broken ends of lying trunks.

Although this is not clear from the map (which emphasizes the occurrence in S Finland due to more active collecting there), $P$. laevigatus is more readily found in N Finland than in the south. In Lapland it can also occur in rather open and well-illuminated Mountain birch (Betula pubescens ssp. tortuosa) forests, which shows that it stands periods of drought during the growing season. In this respect it is more resistant than $P$. lundellii. It is a saprophyte and cannot be regarded as harmful.
The author citation for $P$. laevigatus needs some explanation. There is a name Polyporus laevigatus (Pers.) Duby (Duby 1830), which relates to another, stipitate species. Therefore, in describing Polyporus laevigatus, Fries (1874) created a later homonym. Karsten (1881) transferred the species under discussion to the genus Poria, and so Poria laevigata Karst. seems to be the oldest name available as the basionym for this species of Phellinus. This will not, of course, affect the typification of the species (Niemelä 1972), since the concept of Fries can be traced back through the reference in the study of Karsten (1881).

\section{Phellinus lundellii Niemelä}

$\begin{array}{lccccc} & \begin{array}{c}\text { Whole of } \\ \text { Finland }\end{array} & \text { A-U } & \text { EK-PK } & \text { KP-PP } & \text { Ks-InL } \\ \text { Betula } & 70.0 & 63.1 & 78.1 & 58.7 & 68.4 \\ \text { - pubescens } & 3.7 & & & & \\ \text {-- ssp. tortuosa } & 1.6 & & & & \\ \text { - pendula } & 0.5 & & 17.2 & 34.8 & 21.0 \\ \text { Alnus } & 20.5 & - & & & \\ \text { - incana } & 16.3 & & & & \\ \text { - glutinosa } & 0.5 & & & 6.5 & + \\ \text { Prunus } & 4.3 & 21.0 & - & & \\ \text { - padus } & 3.8 & & & & \\ \text { - domestica } & 0.5 & & & - & 5.9 \\ \text { Populus tremula } & 2.1 & + & + & - & - \\ \text { Corylus avellana } & 1.0 & - & 2.3 & - & + \\ \text { Salix } & 1.0 & - & + & - & - \\ \text { - caprea } & 0.5 & + & - & - & - \\ \text { Pyrus malus } & + & + & - & - & - \\ \text { Sorbus aucuparia } & + & + & & & \\ \text { Host not indicated } & 17 & & & 47 & 38 \\ \text { Specimens } & & & & \\ \text { examined } & 207 & 23 & 99 & \end{array}$

Scattered throughout Finland. More common in the central and northern parts of the country than in the south. This does not, however, indicate any continental character in its distribution: $P$. lundellii is readily found in northern Norway in the Mountain birch stands of the west coast islands around Tromsø, whose climate is most oceanic (personal observation, cf. also Niemelä 1972). In central and northern Finland the species is more common than $P$. laevigatus. The Central European distribution was discussed by Jahn (1977).

The ecology of $P$. lundellii fairly closely resembles that of $P$. laevigatus, though $P$. lundellii has a wider range as regards both the habitat and the host tree species. $P$. lundellii can be found in rather exposed sites if they are microclimatically moist: lake-side al- der thickets, bog birches, etc. It is, however, most often found in dense, old mixed forests, preferably humid. $P$. lundellii is less resistant to temporary drought than $P$. laevigatus.

Everywhere in Finland the favourite host of $P$. lundellii is Betula. The species appears on dead trunks, generally at a later stage than $P$. laevigatus, and fruit bodies can often be found at the base of still standing trunks, or in between the roots of the stumps. These stumps may be very old and moss-covered, which indicates that in suitable places the fruit bodies can continue their growth for decades.

$P$. lundellii may kill trees, especially alder in dense stands, and perhaps also birch. However, we do not regard it as a particularly harmful species from the economic point of view. 

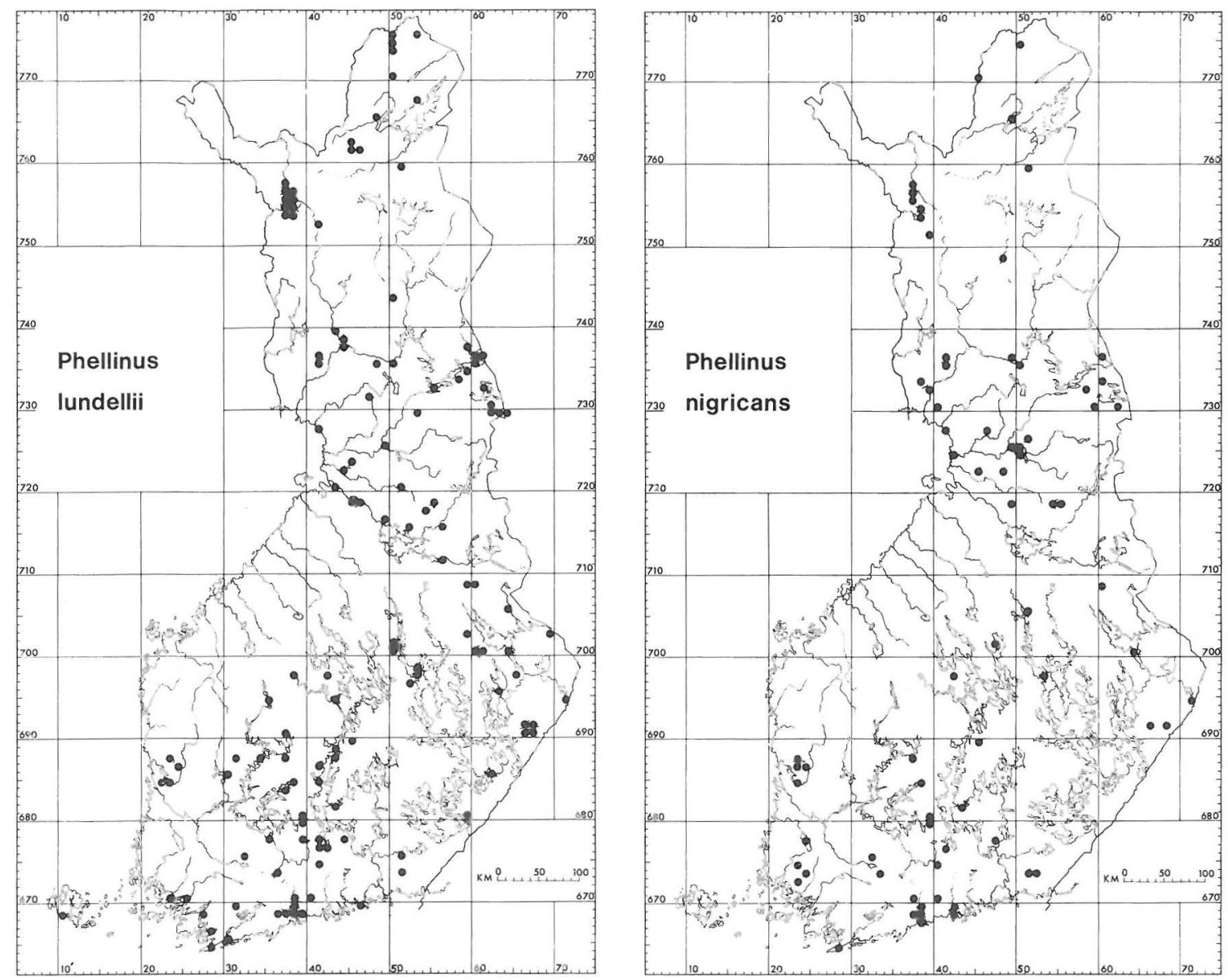

Phellinus nigricans (Fr.) Karst.

Whole of A-U EK-PK KP-PP Ks-InL
Finland

$\begin{array}{lccccc}\text { Betula } & 97.1 & 100 & 95.4 & 92.0 & 100 \\ \text { - pubescens } & 9.4 & & & & \\ \text {-- ssp. tortuosa } & 1.0 & & & & \\ \text { Alnus } & 2.9 & - & 4.6 & + & - \\ \text { - incana } & 2.0 & & & & \\ \text { Host not indicated } & 8 & & & & \end{array}$

\section{Specimens}

examined
18

47

25

22

P. nigricans is found exclusively on dead trees, mostly on big, fallen, still corticate trunks. It is not known whether it kills trees, but because of its rarity its economic importance is in any case small.

Most, if not all, of the records of $P$. nigricans from Central Europe and further south are due to a misunderstanding of the species concept (Niemelä 1975, Jahn 1979). The dark-crusted forms on Fagus, ete., are best referred to $P$. igniarius var. trivialis (Bres. ex Killerm.) Niemelä. 
Phellinus nigrolimitatus (Rom.) Bourd. \& Galz.

$\begin{array}{lccccc} & \begin{array}{c}\text { Whole of } \\ \text { Finland }\end{array} & \text { A-U } & \text { EK-PK } & \text { KP-PP } & \text { Ks-InL } \\ \begin{array}{l}\text { Picea abies } \\ \begin{array}{l}\text { Pinus sylvestris } \\ \text { Ground (buried }\end{array}\end{array} & 80.3 & 90.0 & 72.4 & 94.7 & 97.7 \\ \begin{array}{l}\text { wood?) } \\ \begin{array}{l}\text { Host not indicated } \\ \text { Specimens }\end{array}\end{array} & 1.7 & + & 24.1 & 5.3 & + \\ \text { examined } & 149 & 22 & 36 & 44 & 47\end{array}$

Distributed through the whole of Finland, except the northernmost parts with few or no conifers. Very rare or rare, but in some of the oldest northern spruce forests locally even very common. The distribution shows slight concentration in the north.

When growing in natural forests $P$. nigrolimitatus distinctly favours spruce. In the southern half of the country remarkably many collections have been made from the remains of abandoned hay sheds and other structures made of logs. The wood used in these was mostly pine, which is the reason for the especially high percentage of collections from that host in the zone EK-PK. Some of the collections are from wooden fences. These kinds of occurrences are in sharp contrast with the growth of the species in natural surroundings. As is especially evident in $\mathrm{N}$ and northern C Finland, $P$. nigrolimitatus is an inhabitant of old, dense, almost pure spruce forests, growing chiefly on big trunks that have fallen long ago and are decorticated and covered by a thick carpet of moss. Most of the fruit bodies grow in the shelter of the moss and, being moss-covered themselves, are easily overlooked.

The records from the ground are interesting, and most probably explained by growth on spruce roots partly emerging from the soil and covered by moss. These fruit bodies were very untypical, almost stipitate, and separable from Onnia tomentosa only under the microscope. These finds suggest that the species may - at least exceptionally - be a root parasite.

This is a slow-growing species, ecologically rather similar to $P$. viticola, but more dependent than it on climax-stage forests and higher humidity. It causes a characteristic corrosion rot with regular, dense, ellipsoid pockets of intensive white rot in a less decayed

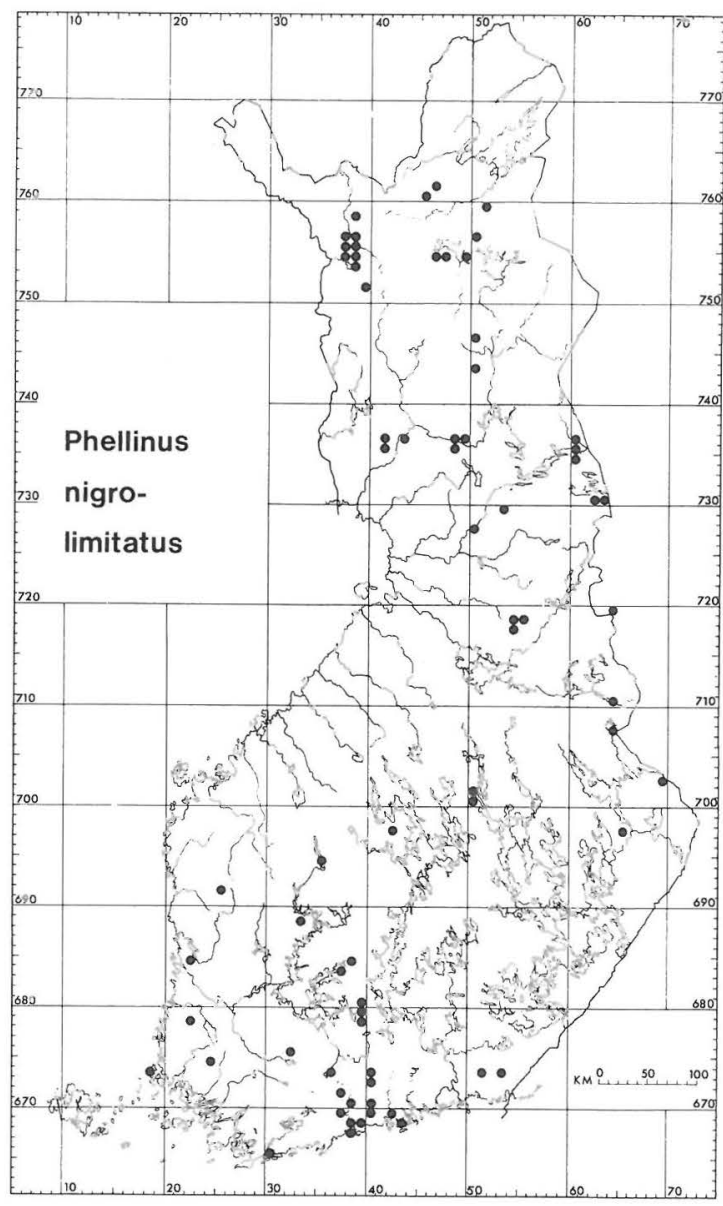
framework. This polypore is of very little economic importance due to its rarity and its occurrence in old forests, in practice mostly protected forest reserves.

Phellinus pini (Brot.) A.Ames

$\begin{array}{lccccc} & \begin{array}{c}\text { Whole of } \\ \text { Finland } \\ 100\end{array} & \text { A-U } & \text { EK-PK } & \text { KP-PP } & \text { Ks-InL } \\ \begin{array}{l}\text { Pinus sylvestris } \\ \begin{array}{l}\text { Specimens } \\ \text { examined }\end{array}\end{array} & 144 & 52 & 67 & 8 & 17\end{array}$


Distributed throughout Finland, but very clearly southern. Fairly common in the oldest stands in southern and southern central Finland, northwards fairly rare to rare, in Lapland very rare. All the Finnish finds are from pine.

The species is very close to $P$. chrysoloma and the two are interesting to compare. The hosts of these species, pine and spruce, are very common over the whole of Finland except the extreme north (Niemelä $1982 \mathrm{~b}$ ), and so the distribution patterns of the two species could be the same. But the difference is clear: $P$. chrysoloma becomes more common northwards and the climate of Lapland (Northern boreal zone) seems to be optimal for it. In contrast, $P$. pini is commonest in the Southern boreal zone of S Finland, and perhaps also in the Hemiboreal southern coastal strip. This in spite of the fact that the best old pine stands are located in the north. This difference strongly supports the separation of these two taxa which, of course, also have macroscopical and microscopical separating characters.

$P$. pini is a parasite causing heart-rot in old, living trees. Its decay proceeds very slowly, and the sapwood and cambium die only around the few fruit bodies. This causes cessation of radial growth in those parts of the trunk, and the sites of the fruit bodies become sunken as the pine stem grows in thickness elsewhere. These depressions in living pines often reveal the presence of $P$. pini before the fruit bodies have become visible. The decay column, and so also the fruit bodies are often situated high in standing trees, and the fungus mostly dies within a few years after the tree has fallen. In this respect $P$. chrysoloma is quite different, having its maximal fruiting only after the fall of the host spruce. P. pini apparently never infects dead pine wood.

The species has been a serious cause of heart-rot in old pine stands. The present rapid-cycle cultivation of pine has decreased the importance of this slowly growing polypore in Finland.

\section{Phellinus populicola Niemelä}

$\begin{array}{lccccc} & \begin{array}{c}\text { Whole of } \\ \text { Finland }\end{array} & \text { A-U } & \text { EK-PK } & \text { KP-PP } & \text { Ks-InL } \\ \text { Populus } & 100 & & & & \\ - \text { tremula } & 89.5 & & & & \\ \text { - alba } & 7.9 & & & & \\ \begin{array}{l}\text { Specimens } \\ \text { examined }\end{array} & 39 & 20 & 12 & 4 & 3\end{array}$

Distributed through almost the whole of Finland, but everywhere rare. A satellite species of $P$. igniarius (rather than $P$. tremulae), this species occurs exclusively on Populus sect. Populus.

This is a parasite of rather old, standing trees. Its pathology differs somewhat from that of $P$. tremulae. $P$. populicola produces only one or a few fruit bodies in a trunk, and they are not restricted to dead bran-

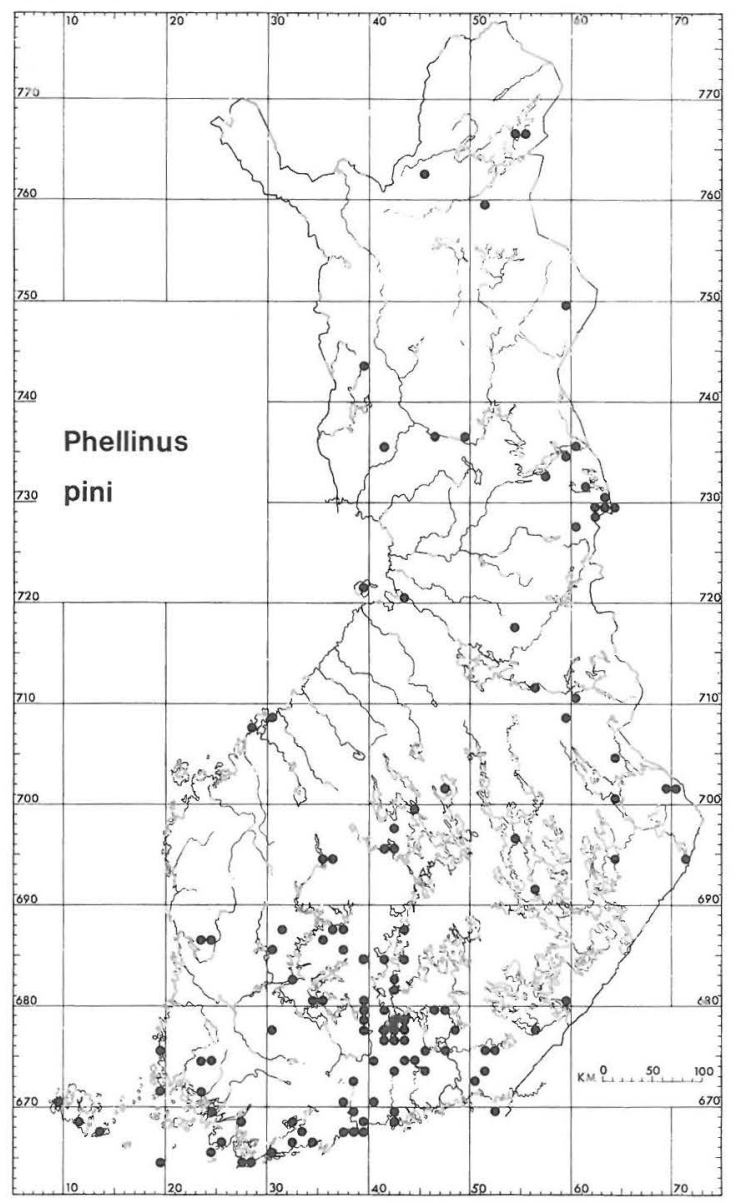

ches. The tree bark dies around the fruit bodies, so that in the course of time a depression is formed. The fruit bodies are very long-living and finally reach a remarkable size. Due to its rarity, $P$. populicola cannot be regarded as an economically important species. It has been treated more comprehensively by Niemelä (1975). 


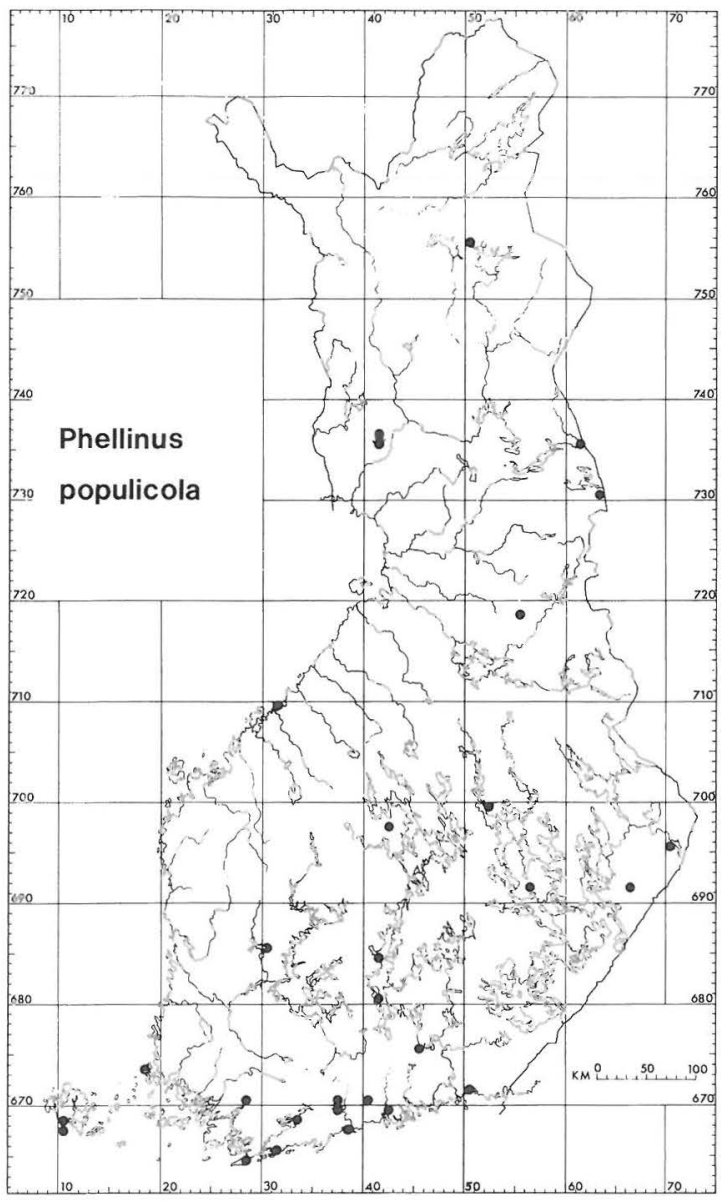

Phellinus punctatus (Karst.) Pilát

Salix

- caprea

- myrsinifolia

- phylicifolia

- nigricans

- cinerea

- X rubens

Corylus avellana

Prunus

- padus

- cerasus

- domestica

Sorbus

- aucuparia

- hybrida

Alnus

- glutinosa

- incana

Populus tremula
Whole of A-U EK-PK KP-PP Finland

$\begin{array}{llll}40.6 & 32.8 & 50.2 & 50.0\end{array}$

25.3

3.2

1.9

1.3

$+$

$+$

21.4

10.7

10.0

$+$

10.4

10.0

$+$

5.5

2.9

1.3

3.6

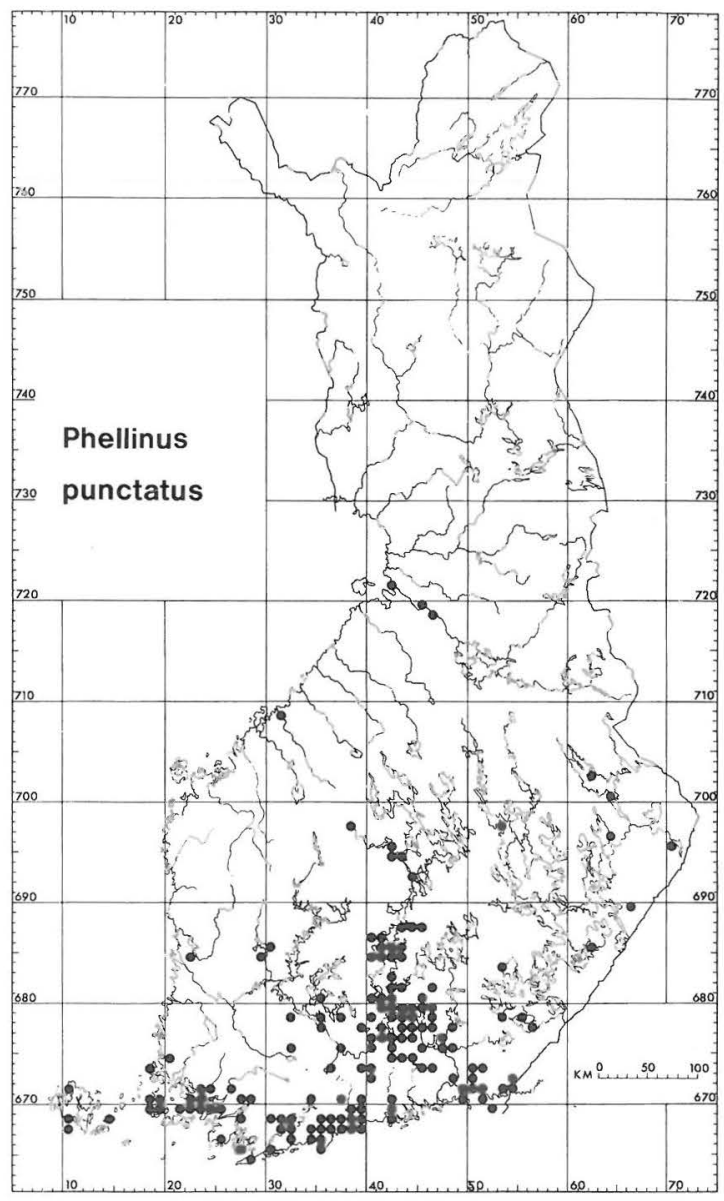

Crataegus

Syringa

- josikaea

- vulgaris

Betula

Lonicera xylosteum

Acer

- ginnala

- platanoides

Frangula alnus

Malus domestica

Virburnum opulus

Host not indicated

Specimens

examined

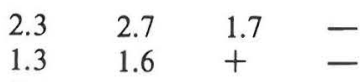

0.6

$+$

$\begin{array}{llll}1.0 & 1.6 & -\end{array}$

$\begin{array}{llll}1.0 & 1.6 & -\end{array}$

$0.6 \quad 1.0 \quad-\quad-$

$+$

$+$

$0.6 \quad 1.0 \quad-\quad-$

$\begin{array}{llll}+ & - & - & - \\ + & + & - & -\end{array}$

40

350

$201 \quad 143$

6

Distribution distinctly southern: fairly common or common in southern Finland, scattered to fairly rare in C Finland, evidently absent from N Finland. So the distribution is Southern boreal - Hemiboreal, with only a few collections from the Middle boreal zone.

The very wide range of hosts in S Finland is a 
characteristic feature for $P$. punctatus. At the northern limits of its distribution the only hosts are Salix caprea and Prunus padus. Corylus avellana is a very common host wherever it occurs. Remarkably many finds have been made on exotic hosts. Although occurring on adult tree trunks, the species can also fruit on the trunks of small shrubs and tree branches, which widens its host spectrum.

$P$. punctatus can be found in very diverse surroundings. It occurs regularly in southern hardwood forests with hazel undergrowth, and also occasionally in mixed spruce forests at the climax stage of succession, mainly on S. caprea or Populus tremula. Generally, however, it is distinctly hemerophilous, taking advantage of the many man-made biotopes: field-edge and roadside thickets, parks, gardens, single trees in open places, etc. At the northern limit of its distribution it follows the main watercourses, and elsewhere, too, $P$. punctatus is remarkably often found close to water. It is locally very common in brookside alder and bird cherry (Prunus padus) thickets and also in paludified hardwood forests.

The species sometimes infects relatively young living alder and aspen trunks, and may even kill them. It causes more harm to park and garden trees and bushes, especially if they are of exotic origin and therefore climatically not well adapted. However, such damage occurs only in isolated cases, and generally speaking $P$. punctatus cannot be included among the harmful species of the genus.

Polyporus punctatus Fries 1874 is a later homonym of Polyporus punctatus Jungh. 1838. The first available basionym for the present species is Poria punctata Karsten 1882.

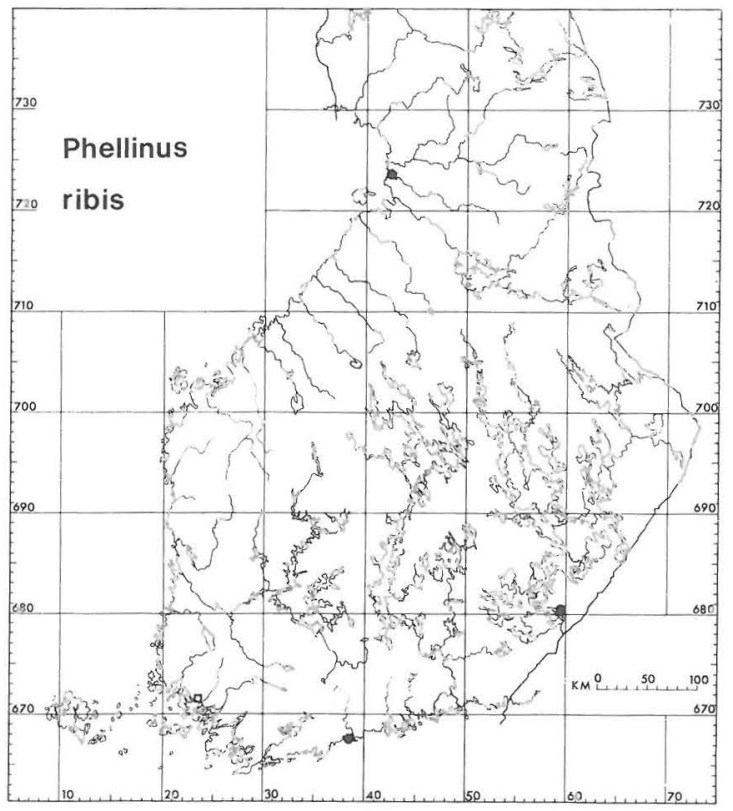

Phellinus ribis (Schum.) Karst.

Whole of U ES PP
Finland

Ribes $\quad 100$

- uva-crispa 60

- rubrum coll. $\quad 40$

Specimens

examined

$$
5
$$$$
3 \quad 1 \quad 1
$$

Very rare in Finland, and recorded only from five remote localities. These finds give no clue to the climatic requirements of the species. See Niemelä (1978). Also reported from Turku by Karsten (1859); this record is indicated on the map by an open square.

Phellinus robustus (Karst.) Bourd. \& Galz.

$\begin{array}{lr} & \text { V } \\ \text { Quercus robur } & 100 \\ \text { Specimens examined } & 27\end{array}$

Very rare in Finland and for almost a hundred years known only from the locus classicus (Turku: Ruissalo/Runsala), from which Karsten (1889) described the species. In that locality the species is abundant, surviving almost annual exploitation by collectors. The other find is fairly recent.

Of no economic importance in Finland, and deserving complete protection.

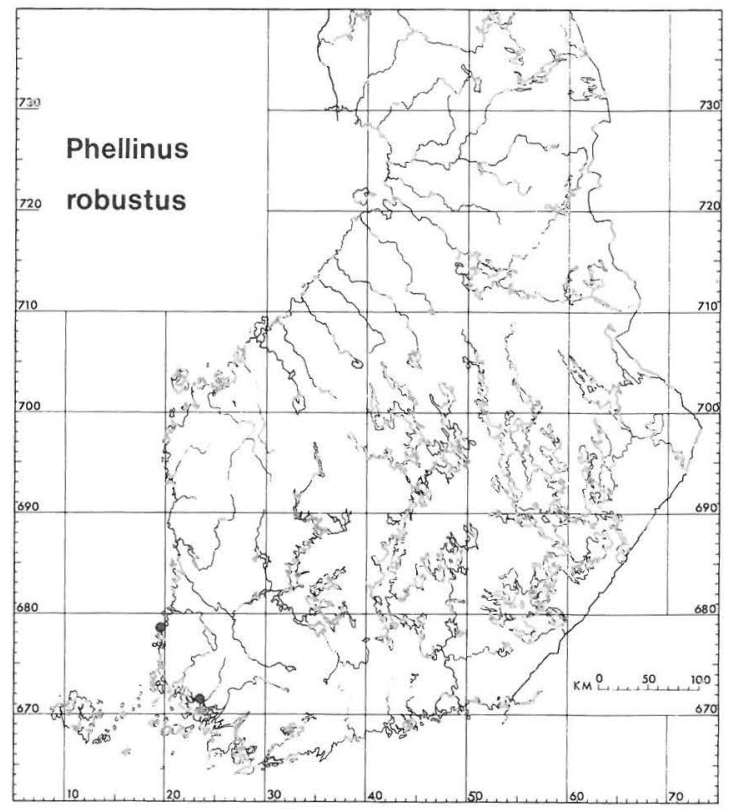


Phellinus tremulae (Bond.) Bond. \& Borisov

\begin{tabular}{|c|c|c|c|c|c|}
\hline & $\begin{array}{l}\text { Whole of } \\
\text { Finland }\end{array}$ & $A-U$ & EK-PK & KP-PP & Ks-InL \\
\hline Populus & 98.8 & 97.8 & 99.0 & 100 & 100 \\
\hline - tremula & 97.0 & & & & \\
\hline - alba & 0.9 & & & & \\
\hline - X canescens & 0.9 & & & & \\
\hline Alnus incana & + & - & + & - & - \\
\hline Quercus robur & + & + & - & - & - \\
\hline Sorbus aucuparia & + & + & - & - & - \\
\hline Host not indicated & 12 & & & & \\
\hline $\begin{array}{l}\text { Specimens } \\
\text { examined }\end{array}$ & 242 & 96 & 95 & 26 & 25 \\
\hline
\end{tabular}

Distributed over the whole country, fairly common to very common. The species is almost exclusively restricted to Populus sect. Populus, of which P. tremu$l a$ is the only indigenous representative in Finland. The records from other host genera are very exceptional, and being unconfirmed are perhaps not quite reliable.

The fungus is represented in almost every stand of aspen, and is the main and almost sole reason for the fact that nearly every fully grown aspen trunk has heart-rot. A typical parasite, $P$. tremulae infects the trees mainly through stubs of dead branches, causing heart-rot through almost the whole length of the trunk, and forming fruit bodies only at the sites where branches have died off. The imperfect knots reported by Černy (1972) have been observed in Finland only occasionally. The fungus does not affect the sapwood, bark, or growth of the cambium, and the trees continue to look healthy until a very late stage of decay. In this respect the symptoms are very different from those of $P$. populicola. It can survive on fallen and dead trunks for many years, through thriving on and infecting only living ones.

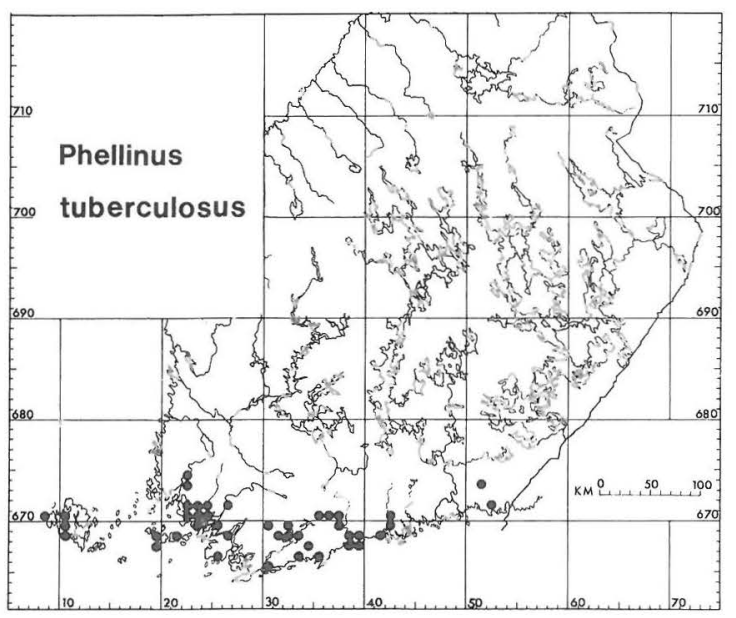

$P$. tremulae can be found in all kinds of sites, in both closed forests and in single, exposed trees. From the economic point of view it must be regarded as one of the most harmful species in the genus. We have no information on the occurrence of $P$. tremulae in plantations of Populus tremula $\times$ tremuloides.

\section{Phellinus tuberculosus (Baumg.) Niemelä}

- Phellinus pomaceus

$\begin{array}{ccc}\begin{array}{c}\text { Whole of } \\ \text { Finland }\end{array} & \text { A-U } & \text { EK } \\ & & \\ 95.3 & 95.2 & 100 \\ 34.4 & & \\ 29.7 & & \\ 17.2 & & \\ 4.7 & & \\ 3.1 & 3.2 & - \\ 1.6 & & \\ 1.6 & & \\ 1.6 & 1.6 & - \\ & & \\ 64 & 62 & 2\end{array}$

A distinctly southern species, and in Finland restricted roughly to the Hemiboreal zone, although the hosts are distributed much farther north. Within its distribution, $P$. pomaceus occurs fairly regularly in abandoned or neglected orchards, and may be regarded as fairly common.

The main host genus is Prunus, excluding subg. $\mathrm{Pa}$ dus (strongly represented in Finland by Prunus pa$d u s)$. In Finland the species causes only minor harm to cultivated Prunus domestica and P. cerasus.

The North-European distribution, pathology and other characters were studied more closely by Niemelä (1977). The necessity for the change of name (Niemelä 1982a) had already been pointed out by Demoulin et al. (1981). We have checked it in Donk (1974). 

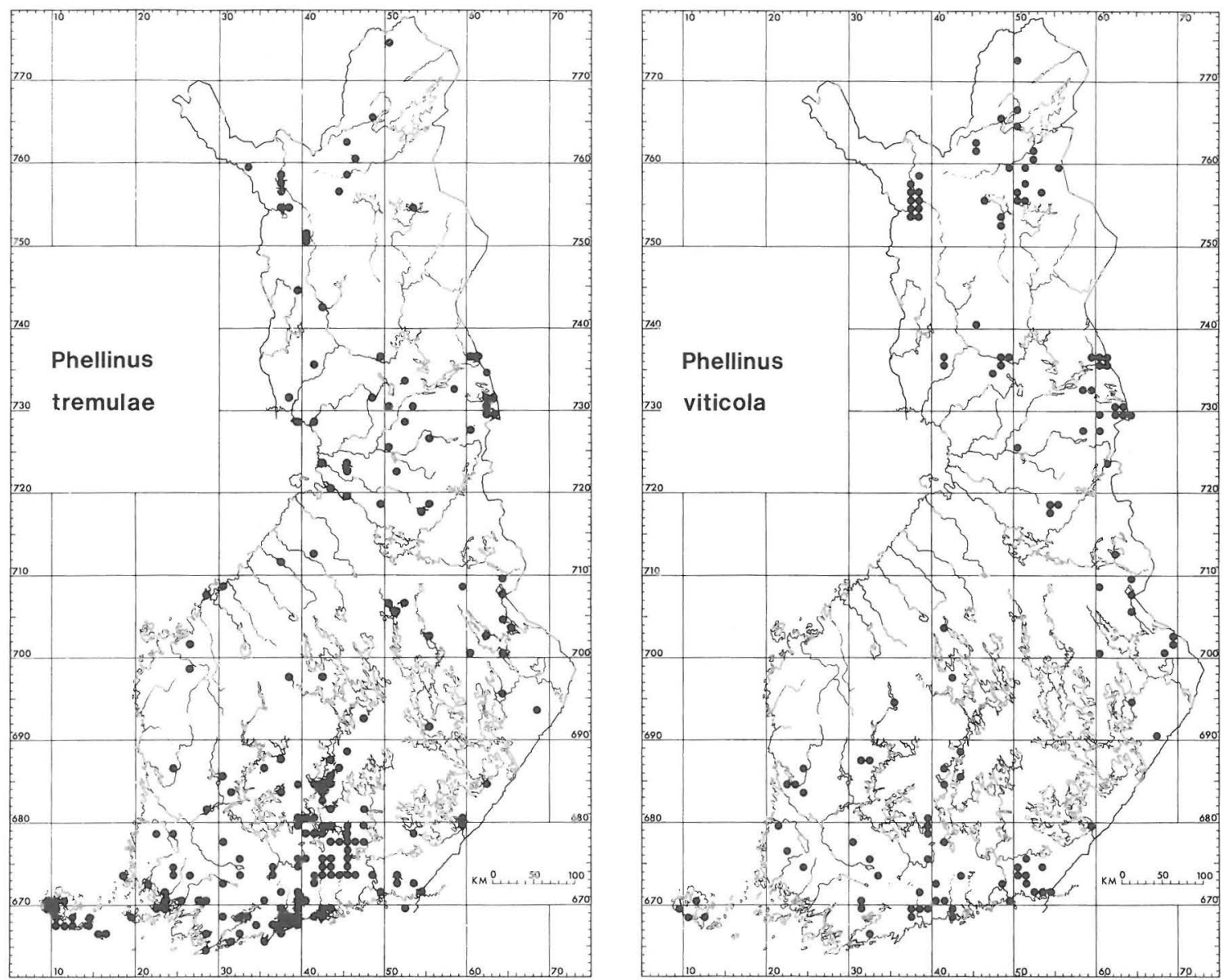

Phellinus viticola (Schw. ex Fr.) Donk

$\begin{array}{lccccc} & \begin{array}{c}\text { Whole of } \\ \text { Finland }\end{array} & \text { A-U } & \text { EK-PK } & \text { KP-PP } & \text { Ks-InL } \\ & 62.4 & 93.4 & 53.9 & 79.5 & 43.6 \\ \begin{array}{l}\text { Picea abies } \\ \text { Pinus sylvestris }\end{array} & 36.6 & + & 46.1 & 18.2 & 56.4 \\ \begin{array}{l}\text { Betula } \\ \begin{array}{l}\text { Populus tremula } \\ \text { Host not indicated }\end{array}\end{array} & + & - & - & + & - \\ \begin{array}{l}\text { Specimens } \\ \text { examined }\end{array} & 58 & + & - & - & - \\ & 265 & 43 & 111 & 47 & 64\end{array}$

Distributed throughout Finland. Fairly rare to scattered and in rich virgin spruce forests in N Finland even very common. The distribution has a slight but distinct northern character.

This is the only Finnish representative of Phellinus which indisputably occurs on both conifers and hardwoods. The main host is spruce, especially in $\mathrm{S}$ Finland. Towards the north the proportion of pine increases, evidently partly because spruce is less common than pine in northernmost Finland. P. viti-

cola can be found on broken fences even more often than $P$. nigrolimitatus, especially in $\mathrm{S}$ and $\mathrm{C}$ Finland. Its ecological amplitude is distinctly wider than that of $P$. nigrolimitatus: it can be collected in both welldrained or dry sites, shady or exposed habitats, from thick or thin fallen trunks, corticate or bare wood, etc. However it clearly favours dense, rich spruce focorticate, fallen trunks. Its life cycle is distinctly more rapid than that of $P$. nigrolimitatus, and the rot is softer and progresses more rapidly. 
It is not known whether $P$. viticola kills spruce trees, but this is possible, especially in the northern forests, and is suggested by the extensive butt rot and the abundance of fruit bodies at the bases of fallen trees. The occurrence on fences, on the other hand, indicates that it can start life as a saprophyte. Though not one of the worst decay-causing species of the genus, $P$. viticola does do some damage to dense spruce stands in $\mathrm{N}$ and NE Finland.

Acknowledgements. Financial support of the Academy of Finland (during 1980-1981) and Suomen Kulttuurirahasto (to the author Kotiranta, 1982) is gratefully acknowledged.

\section{References}

Bondarceva, M. 1963: Obzor poryadka Aphyllophorales Leningradskoj oblasti. - 447 pp., 50 tab., stenciled. Leningrad.

Čerńy, A. 1972: Phellinus tremulae (Bond.) Bond. et Borisov, a most serious fungal parasite of aspen trees. Acta Univ. Agric. Brno (Ser. C) 41: 131-149.

Demoulin, V., Hawksworth, D., Korf, R. \& Pouzar, Z. 1981: A solution of the starting point problem in the nomenclature of fungi. - Taxon 30: 52-63.

Donk, M. 1964: A conspectus of the families of Aphyllophorales. - Persoonia 3: 199-324.

- 1974: Check list of European polypores. - 469 pp. Amsterdam.

Duby, J. 1830: Botanicon Gallicum 2. - Pp. 545-1068. Paris.

Eckblad, F.-E. 1981: Soppgeografi. - 168 pp. Oslo.

Eriksson, J. 1958: Studies in the Heterobasidiomycetes and Homobasidiomycetes-Aphyllophorales of Muddus National Park in North Sweden. - Symb. Bot. Upsalienses 16(1): $1-172$.

Eriksson, J. \& Strid, A. 1969: Studies in the Aphyllophorales (Basidiomycetes) of northern Finland. - Ann. Univ. Turkuensis (A II) 40 (Rep. Kevo Subarctic Sta. 4): $112-158$.

Fries, E. 1874: Hymenomycetes Europaei. - 755 pp. Upsaliae.

Jahn, H. 1965: Die Phellinus robustus var. hippophaes $\mathrm{Ph}$. contiguus-Ass., eine Pilzgesellschaft auf Sanddorn. - Westfäl. Pilzbriefe 5: 139-141.

- 1967: Die resupinaten Phellinus-Arten in Mitteleuropa. - Westfäl. Pilzbriefe 6: 37-108.

- 1976: Phellinus hippophaecola H. Jahn, a new species. Mem. New York Bot. Gard. 28: 105-108.

- 1977: Phellinus lundellii Niemelä und sein Vorkommen in Deutschland (BRD). - Westfäl. Pilzbriefe 11: 59-66.

- 1979: Pilze die an Holz wachsen. - 268 pp. Herford.

- 1981: Die resupinaten Phellinus-Arten in Mitteleuropa. Nachträge 1967-1981. - Bibliotheca Mycol. 81: $109-151$.

Jülich, W. 1981: Higher taxa of Basidiomycetes. - 485 pp. Vaduz.
Karsten, P. 1859: Sydvestra Finlands polyporeer. - 47 pp. Helsingfors.

- 1881: Symbolae ad mycologiam Fennicam 8. - Medd. Soc. Fauna Flora Fennica 6: 7-13.

- 1882: Rysslands, Finlands och den Skandinaviska halföns hattsvampar. Sednare delen: pip-, tagg-, hud-, klubb- och gelésvampar. - Bidr. Känned. Finlands Nat. Folk 37: 1-257.

- 1889: Kritisk öfversigt af Finlands basidsvampar. Bidr. Känned. Finlands Nat. Folk 48: 1-470.

Korf, R. 1982: Citation of authors names and the typification of names of fungal taxa published between 1753 and 1832 under the changes in the Code of Nomenclature enacted in 1981. - Mycologia 74: 250-255.

Kotiranta, H. \& Niemelä, T. 1981: Composition of the polypore communities of four forest areas in southern Central Finland. - Karstenia 21: 31-48.

Kotlaba, F. 1968: Phellinus pouzarii sp.nov. - Česká Mykol. 22: 24-31.

Laine, L. 1967: Notes on the polypores (Polyporaceae) of Ahvenanmaa. - Karstenia 6-7: 14-20.

Larsen, M. \& Lombard, F. 1976: Phellinus fragrans sp.nov. (Aphyllophorales, Hymenochaetaceae) associated with a white rot on maple. - Mem. New York Bot. Garden 28: $131-140$.

Niemelä, T. 1971: On Fennoscandian polypores 1. Haploporus odorus (Sommerf.) Bond \& Sing. - Ann. Bot. Fennici 8: $237-244$.

- 1972: On Fennoscandian polypores 2. Phellinus laevigatus (Fr.) Bourd. \& Galz. and P. lundellii Niemelä n.sp. - Ann. Bot. Fennici 9: 41-59.

- 1974: On Fennoscandian polypores 3. Phellinus tremulae (Bond.) Bond. \& Borisov. - Ann. Bot. Fennici 11: 202-215.

- 1975: On Fennoscandia polypores 4. Phellinus igniarius, P. nigricans and P. populicola n.sp. - Ann. Bot. Fennici 12: $93-122$.

- 1977: On Fennoscandian polypores 5. Phellinus pomaceus. - Karstenia 17: 77-86.

- 1978: The occurrence of some rare pore fungi in Finland. - Ann. Bot. Fennici 15: 1-6.

- 1982a: Taxonomic notes on the polypore genera Antrodiella, Daedaleopsis, Fibuloporia and Phellinus. Karstenia 22: 11-12.

- 1982b: Polypore survey of Finland 1. Introduction. Karstenia 22: 21-26.

Norokorpi, Y. 1979: Old Norway spruce stands, amount of decay and decay-causing microbes in northern Finland. - Comm. Inst. Forest. Fenniae 97(6): 1-77.

Parmasto, E. 1976: Studies on Yakutian fungi 2. Ganodermataceae, Hymenochaetaceae, Polyporaceae s.str. Eesti NSV Tead. Akad. Toim. 25 (Biol. 4): 316-321.

Rousi, A. 1971: The genus Hippophae L. A taxonomic study. - Ann. Bot. Fennici 8: 177-227.

Ryvarden, L. 1978: The Polypores of North Europe 2. Inonotus to Tyromyces. - Pp. 219-507. Oslo.

von Schulmann, O. 1960: Zur Kenntnis der Basidiomyceten Finnlands. - Karstenia 5: 5-99.

Stenlid, G. 1947: Några anteckningar om Ålands svampflora. - Mem. Soc. Flora Fauna Fennica 23: 82-90.

Vuoristo, A. 1972: Tyrnipensaasta ja sen esiintymisestä Rauman saaristossa vuosina 1970-1971. - Unfinished manuscript, University of Turku.

Vucristo, A. \& Rousi, A. 1976: Changes during 35 years in the range of Hippophae rhamnoides in the archipelago of Rauma on the Gulf of Bothnia coast. - Aquilo, Ser. Bot. 14: 1-5. 